\title{
INFLUENCES OF ENVIRONMENTAL DRIVERS ON LAND COVER STRUCTURE AND ITS LONG-TERM CHANGES: A CASE STUDY OF THE VILLAGES OF MALACHOV AND PODKONICE IN SLOVAKIA
}

\author{
Michal DRUGA, Vladimír FALŤAN
}

\begin{abstract}
The influence of environmental drivers on long-term land cover changes in two mountainous villages in Central Slovakia is assessed in this paper using generalized linear models (GLM). Historical cadastral maps and aerial photographs were analyzed to describe the land cover change over five time horizons ranging from 1860 to the present, using the CORINE Land Cover classification. The hypothesis that higher slope, elevation and distance to settlement strongly influence lower intensities of land use was mostly confirmed, but geology was also identified as an important factor. The category of 'forests' was the most accounted for land cover class, while arable land and grassland were only considerably affected by the drivers in some periods. On the other hand, shrubs were almost completely unrelated to the investigated drivers. The areas of land cover change were not so well explained by the GLMs.
\end{abstract}

\section{Shrnutí}

\section{Vliv environmentálních podmínek na strukturu krajinného pokryvu a její dlouhodobé změny: prípadová studie obcí Malachov a Podkonice na Slovensku}

Předkládaná studie hodnotí vliv environmentálních podmínek na dlouhodobé změny krajinného pokryvu ve dvou horských obcích na středním Slovensku, a to s využitím krabicových grafü, jednoduché logistické regrese a generalizovaných lineárních modeli (GLM). S využitím klasifikace CORINE Land Cover je analyzován krajinný pokryv na historických katastrálních mapách a leteckých snímcích v pěti historických horizontech od r. 1860 do současnosti. Hypotéza, že větši sklon, nadmořská výška a vzdálenost $k$ sídlům je příčinou menši intenzity využívání krajiny byla do značné míry potvrzena, avšak k významným faktorům patřilo i geologické podloží. Modely nejlépe vysvětlitelnou třídou krajinného pokryvu byly lesy; lokalizace orné půdy a travních porostů byla $v$ některých zkoumaných obdobích rovněž značně ovlivněna zkoumanými podmínkami, zatímco lesokřoviny na nich byly prakticky nezávislé. Velikosti ploch změn krajinného pokryvu byli pomocí GLM relativně méně vysvětlitelné.

Keywords: land cover change, farmland abandonment, environmental conditions, driving forces, generalized linear models, CORINE, Malachov, Podkonice, Slovakia

\section{Introduction}

The structure of a cultural landscape is largely determined by human decisions - by direct or indirect impacts of human activities, or by choice of land abandonment. This decision-making process is not chaotic, but rather, judiciously based on many factors - the "drivers" of land cover change. Changes in landscape structure significantly affect its ecological stability (Lipský, 2001), as well as its biological (Löfvenhaft et al., 2004), environmental and aesthetic values (Nassauer, 1995). The investigation of driving forces has therefore developed into an important research topic recently.

Studies of land cover drivers use miscellaneous methodologies, as there are different ways of understanding and studying them at different spatial scales and in temporal periods. It is suitable to determine the motivation of all relevant stakeholders, either through oral history interviews or studying relevant historical documents (e.g. Bürgi et al., 2004; Mottet et al., 2006; Domon, Bouchard, 2007; Schneeberger et al., 2007; Calvo-Iglesias et al., 2009). The disadvantage of this approach is the weaker availability of information for larger areas and longer time periods, as well as the fact that the obtained information can often be nonspatial. Therefore it is difficult to quantify their impact on land cover changes, which are spatial in their nature.

Hence, many studies apply spatially explicit characteristics of environmental and socio-economic conditions as drivers. These drivers affect land-use decision making indirectly, or they explain the background to the decision making. Although this approach does not directly explain reasons for the changes, it profits from: better spatial and temporal availability of the drivers data (Hietel et al., 2004); their better comparability between different areas; and more exact statistical methods, which are then possible. One of the main motivations for research on the driving forces of landscape change is to find general patterns, valid beyond the specific situation under study (Bürgi et al., 2004).

Spatial drivers have been widely used in recent research studies. Wear and Bolstad (1998) highlighted elevation, slope and distance to roads as important factors in land use change, and their importance was also confirmed in deforestation models by Schneider and Pontius (2001). 
Many more environmental drivers were used by Rutherford and Bebi $(2007,2008)$ to assess the land cover change drivers in Switzerland; and also by Tasser (2007) in a local study of natural reforestation on alpine pastures. Hietel (2004) recommended the use of socio-economic variables to increase the land cover change variance accounted for, rather than using the environmental drivers alone. Yet, later he stated that socio-economic drivers themselves cannot explain land cover changes, but combined with the environmental drivers they can faciliate the reconstruction of the changes (Hietel et al., 2005).

On the other hand, both environmental and socioeconomic drivers were significantly associated with land use changes in a study of marginal agricultural landscapes in Portugal (Van Doorn, Bakker, 2007). Gellrich et al. (2007) also succesfully applied both types of spatial drivers to confirm the hypothesis that forest regrowth takes place where cultivation costs are high and yield potential low. Most socio-economic spatial drivers are only available at the municipality level, however. Because many land cover changes are detected only at more detailed scales, the focus here is on the drivers which are spatially distinguishable at these scales.

Topography seems to be the most common environmental driver utilized in land cover change studies. Elevation is applied as a proxy for temperature gradient (Rutherford, Bebi, 2008), to distinguish flood areas (Schneider and Pontius, 2001), but also to determine the vertical zonality of soils (Florinsky, Kuryakova, 1996). Slope is a typical driver utilized to represent cultivation costs in the area (Gellrich et al., 2007). Higher values of slope angle were shown to be correlated with higher land abandonment and reforestation in Indiana (Harrison et al., 2008), the German Highlands (Hietel et al., 2004), the Alps (Tasser et al., 2007), the Pyrenees (Mottet et al., 2006), and many other areas.

Its influence, however, does not necessarily need to be linear (Gellrich et al., 2007; Schneider, Pontius, 2001). Similar effects of slope were reported also in the postsocialist development of land use in Albania (Müller, Munroe, 2008) and the Czech republic (Havlíček, Chrudina, 2013). On the other hand, farmland abandonment was lower in areas with higher slope and elevation in Western Ukraine in the same period, highlighting the fact that socio-economic reasons for abandonment differ also among postsocialist countries (Baumann et al., 2011).

The importance of the influence of slope aspect on land cover was secondary, according to Hietel et al. (2004), but a study of permanent meadows loss in the Alps showed that its effect is significant (Monteiro et al., 2011). Because aspect represents site conditions only indirectly, insolation or solar radiation are preferred in some recent studies (Martínez, 2011; Rutherford, Bebi, 2008; Serra et al., 2008).

The accessibility of areas is one of the most important attributes determining land cover, which has been paid attention since the first land use model (von Thunen, 1826). Many studies have confirmed its strong effect on land cover structure and its changes, such as farmland abandonment (Mottet et al., 2006; Müller and Munroe 2008; Müller et al., 2009; Prishchepov et al., 2013; Wu and Zhang, 2012). Löw stated that the maximum commuting distance from village to fields, established in Czech lands from the $13^{\text {th }}$ century until the introduction of mechanization, was $1.2 \mathrm{~km}$ (Löw, Míchal, 2003). Gellrich (2007) described a non-linear relationship of forest re-growth and the distance from roads in Switzerland, where re-growth decreases at very large distances due to the fact that remoteness has only minor effects on alpine pastures.

The effects of the spatial drivers slightly differ in the various regions of Europe, reflecting different levels of socioeconomic development. Since Slovakia is historically situated in the cultural and political influence of Western and Eastern Europe, research in this country is promising.

Significant socio-economic changes have influenced development in the region of the former Austro-Hungarian Monarchy during last 150 years. These changes are well described by Bičík et al. (Bičík et al., 2001): the freeing of a large labour force after the abolition of serfdom in 1848 led to extensive economic development and use of resources. Expansion of agricultural lands was not possible after the 1880s, therefore technological changes led to industrialization and agricultural intensification in fertile lowland areas. Later, the intensity of land use was positively influenced by an extensive land reform and partial breaking apart of the large estates after the establishment of the Czechoslovak Republic in 1918, but negatively affected by the increasing competition of cheaper imported grain, both World Wars and economic crises. After WWII, continuing general economic tendencies and farm collectivization led to a serious agricultural extensification in less fertile regions and further intensification in lowlands, but large areas of agriculural land were confiscated for non-agricultural activities. The most important processes after the 'Velvet Revolution' in 1989 were: (i) the reintroduction of a market economy; (ii) the restitution of private property and partial privatization of state property; (iii) the transformation of agricultural co-operatives into agricultural stock companies, or co-operatives where the legal rights of landowners are respected; and (iv) an increasing environmental awareness among the population.

Even so, only scant attention has been paid to the spatial drivers of land cover change in Slovakia. Land cover changes themselves are relatively well described at the national level (e.g. Feranec, Nováček, 2009) and some regional and local studies specified these changes at a more detailed scale (Cebecauerová and Cebecauer, 2008; Kopecká, 2006; Oláh et al. 2006; Boltižiar et al., 2008; Ivanová et al., 2012). Spatial correlation between topographic factors and land cover was assessed by Š́ri (2003) and Kandrík, Oláh (2010). Senko modelled land cover and vegetation change using insolation, precipitation and soil temperature drivers (Senko et al., 2008), and Faltan presented studies on the windthrow impact on vegetation on various "geotope" sites in the High Tatra foothills (Faltan, Pazúrová, 2010; Faltan et al., 2011). Oláh (2003) interpreted land use change in the Podpol'anie region, by land-use form affinity to landscape-ecological complex components. The study by Lieskovský et al. (2013), analysing the driving forces of vineyard abandonment, appears to be the only work explicitly focusing on spatial land cover change drivers in Slovakia.

Following on from the above-mentioned works, this study attempts to describe the influence of spatially explicit environmental drivers on land cover structure and its changes in mountainous rural regions in Slovakia. Because the influence of drivers may change over time (Aspinall, 2004), we tried to use historical sources depicting land cover, (1) with sufficent cartographic precision and (2) for a long period of time. For these purposes, 
aerial imaging since 1949 and historical cadastral maps from 1860 have proven beneficial. We focused on the research of small areas at a detailed scale, because many important land cover change processes and driver influences are only detectable at these scales. Therefore, the areas surrounding the villages of Malachov and Podkonice in central Slovakia were chosen for analysis (Fig. 1). Various statistical methods have been used worldwide to quantify the effects of drivers. Because logistic regression is one of the methods most often utilized to describe the influence of land cover change drivers (Rutherford, 2007), and generalized linear models have proven to be a useful tool for land cover change modelling (Millington et al., 2007), these methods were applied in our study.

We focused on following research questions:

1. which land cover changes occurred during the research period?;

2. which environmental drivers mostly influenced the land cover and its changes?; and

3. which land cover classes and which changes were mostly influenced by the synergic effect of environmental drivers?

Acording to the literature review above, we formulated the following partial hypotheses:

- higher slope, elevation and distance to settlement are related to the classes with lower intensities of use, and therefore they have:

1. a negative influence on the localization of builtup areas, arable land, and processes of agricultural intensification and urbanization; and
2. a positive indirect influence on the localization of forests, shrubs, and processes of agricultural extensification; and

- higher solar radiation should positively influence the suitability for agricultural cultivation.

\section{Material and methods}

Spatial land cover data, serving as dependent or response variables for the regression models, were obtained from different sources. While cadastral maps for Malachov in 1860 and Podkonice in 1866 provided data for the $19^{\text {th }}$ century, aerial photo-grammetric images from 1949, 1968 (1961 for Podkonice) and 1986 depicted $20^{\text {th }}$ century changes. Current land cover was described using orthophotomaps from 2006, revised by detailed field research in the summer of 2011.

Historical cadastral maps and aerial images were geo-rectified to identify land cover class polygons. We used the $4^{\text {th }}$ level CORINE Land Cover method for this classification (Feranec, Otahel, 1999), with minor changes to reflect the detailed scale of 1:10 000 in this study. The minimal mapping unit was set at 0.25 ha and some classes were defined more specifically (Tab. 1). In addition, land cover classes were aggregated in six generalized classes for most analyses (Tab. 1).

Descriptive statistics outlined changes in land cover in the observed period and determined the most significant processes. Each land cover class from each available year was converted to a separate binary layer for regression modelling (i.e., its presence or absence). Finally, land cover

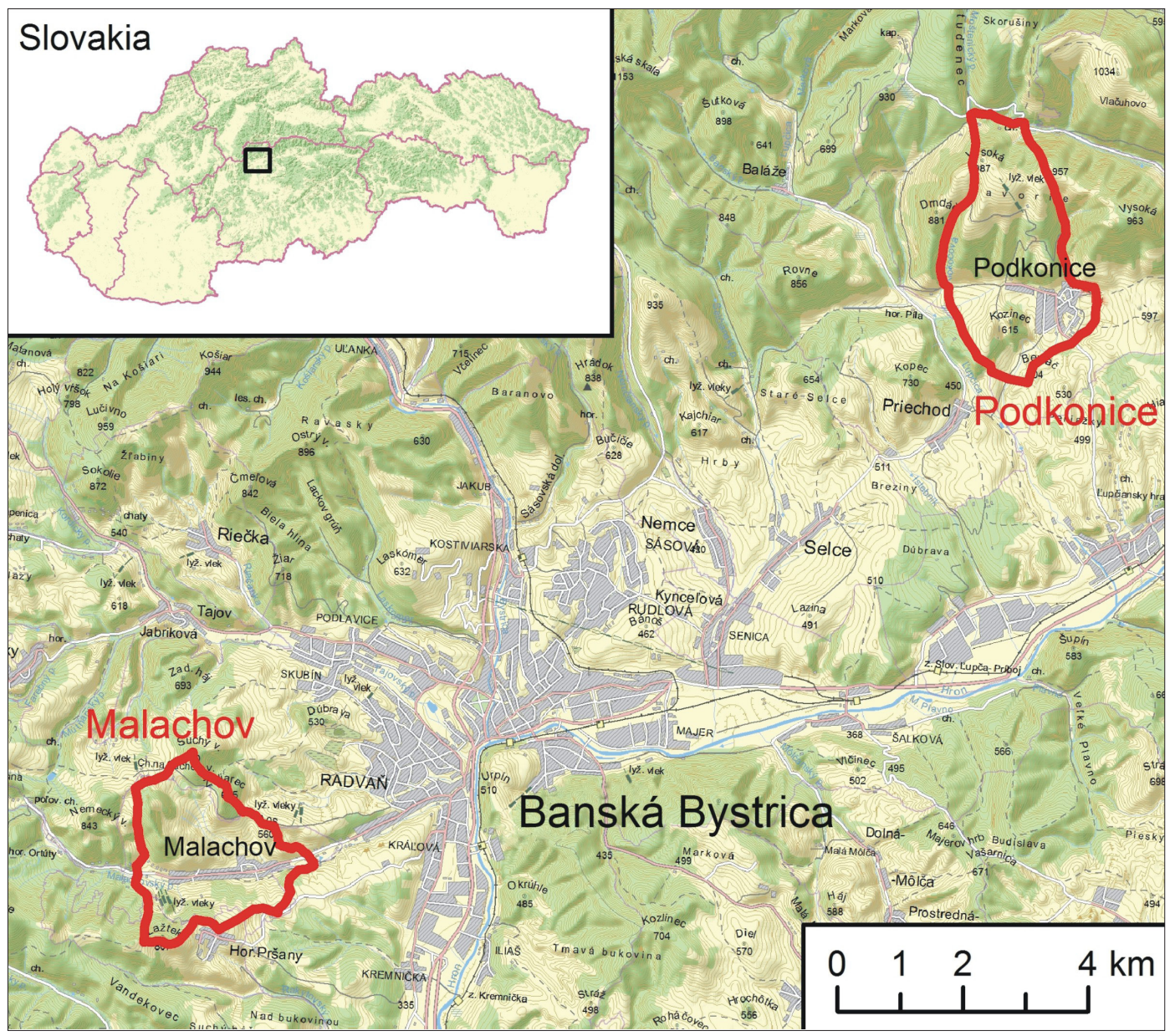

Fig. 1: The geographical situation of the study areas 


\begin{tabular}{|c|c|c|c|}
\hline $\begin{array}{l}\text { CLC } 4 \\
\text { code }\end{array}$ & CLC 4 name of the class & Description of the class & $\begin{array}{l}\text { Generalized } \\
\text { land cover class }\end{array}$ \\
\hline 1.1.2.2 & $\begin{array}{l}\text { Discontinuous built-up areas } \\
\text { with family houses }\end{array}$ & $\begin{array}{l}\text { build-up areas in villages, including buildings and } \\
\text { courts, without adjacent gardens, fields or lawns }\end{array}$ & artificial surfaces (1) \\
\hline 1.2.1.1 & Industrial and commercial units & mostly areas of cooperative agricultural farms & artificial surfaces (1) \\
\hline 1.2.2.1 & Road network and associated land & visible areas of roads & artificial surfaces (1) \\
\hline 1.3.1.2 & Quarries & areas of quarries & artificial surfaces (1) \\
\hline 1.3.3.1 & Construction sites & areas under construction development & artificial surfaces (1) \\
\hline 1.4.1.2 & Cementeries & areas of cementeries & artificial surfaces (1) \\
\hline 1.4.2.1 & Sport facilities & areas of playgrounds with associated buildings & artificial surfaces (1) \\
\hline 1.4.2.2 & Leisure areas & areas of recreational cottages & artificial surfaces (1) \\
\hline 2.1.1.1 & Arable land & areas of arable land & arable land (2) \\
\hline 2.2.2.1 & Orchards & areas of fruit orchards & permanent crops (2.2) \\
\hline 2.3.1.1 & $\begin{array}{l}\text { Grassland prevailingly } \\
\text { without trees and shrubs }\end{array}$ & $\begin{array}{l}\text { areas of grassland prevailingly without trees } \\
\text { and shrubs (less than 15\%) }\end{array}$ & grassland (2.3) \\
\hline 2.3.1.2 & Grassland with trees and shrubs & areas of grassland with trees and shrubs $(15-40 \%)$ & grassland (2.3) \\
\hline 2.4.2.1 & $\begin{array}{l}\text { Complex cultivation patterns } \\
\text { without scattered houses }\end{array}$ & $\begin{array}{l}\text { small patches of fruit orchards, annual and } \\
\text { permanent crops, belonging to village houses }\end{array}$ & permanent crops (2.2) \\
\hline 2.4 .2 .2 & $\begin{array}{l}\text { Complex cultivation patterns } \\
\text { with scattered houses }\end{array}$ & $\begin{array}{l}\text { small patches of fruit orchards, annual and } \\
\text { permanent crops with scattered cottages }\end{array}$ & permanent crops (2.2) \\
\hline 3.1.1 & Broad-leaved forests & areas of broad-leaved forests & forests $(3.1)$ \\
\hline 3.1 .2 & Coniferous forests & areas of coniferous forests & forests $(3.1)$ \\
\hline 3.1.3 & Mixed forests & areas of mixed forests & forests $(3.1)$ \\
\hline 3.2.4.1 & $\begin{array}{l}\text { Transitional woodland-scrub: } \\
\text { Young stands after cutting }\end{array}$ & $\begin{array}{l}\text { areas of young stands planted by man after } \\
\text { cutting, or glades }\end{array}$ & shrubs $(3.2 .4)$ \\
\hline 3.2.4.2 & $\begin{array}{l}\text { Transitional woodland-scrub: } \\
\text { Natural young stands }\end{array}$ & areas of natural forest regeneration/recolonization & shrubs (3.2.4) \\
\hline 3.2.4.3 & $\begin{array}{l}\text { Transitional woodland-scrub: } \\
\text { Bushy woodlands }\end{array}$ & $\begin{array}{l}\text { areas formed by shrubs (Juniperus, Crataegus, } \\
\text { Rosa, etc.) along with grassland and dispersed } \\
\text { trees, which do not form continuous canopy }\end{array}$ & shrubs $(3.2 .4)$ \\
\hline
\end{tabular}

Tab. 1: Definition of the land cover classes, used for the classification and for further analysis

change areas were aggregated into three major land cover flows (Feranec et al., 2010):

1. agricultural extensification: including transitions from arable land, or gardens and orchards, to grassland, to grassland with scattered trees and shrubs, to shrubs, or to forest;

2. agricultural intensification: including the opposite transitions to those in extensification; and

3. urbanisation: including transitions to artificial surfaces.

\begin{tabular}{|l|c|}
\hline \multicolumn{1}{|c|}{ Predictor variable } & Unit \\
\hline Elevation & $\mathrm{m}$ \\
\hline Slope & $\circ$ \\
\hline Sine of aspect & -1 to 1 \\
\hline Radiation & $\mathrm{kJ} / \mathrm{day}$ \\
\hline Topographic wetness index & index \\
\hline Distance to settlement & $\mathrm{m}$ \\
\hline Geological substrate & multinominal \\
\hline
\end{tabular}

Tab. 2: Environmental drivers used as predictor variables in regression models
The spatial extents of these processes were also used as response variables in the regression models for each period between subsequent years, and for 1949-2011 to assess total change in the most turbulent period. Besides the assessment of the land cover change, recognition of areas without change during the observed period is of utmost importance, and these are assessed in the models as "stable areas".

Maps of the relevant spatial and biophysical drivers with raster layers of $2 \mathrm{~m}$ resolution were used as independent (predictor) variables for regression modelling. According to the studies mentioned in the Introduction, the following seven spatial drivers were used in this study: elevation, slope, aspect, insolation, distance to settlement, topographic wetness index (TWI) and geological substrate (Tab. 2).

The raster for direct distance to the settlement was created by the ArcGIS distance module, and geological substrate information was obtained by vectorizing quaternary geological maps scaled at 1:50000 and held at Štátny geologický ústav Dionýza Štúra (2011). The remaining drivers were derived from DEM, computed in the GRASS GIS RST module (spline: 0.1; tension: 40). The contours of a topographic map at 1:10 000 scale were utilized as DEM interpolation input. The terrain aspect was substituted by its sine function, thus defining its southerly aspect (Rutherford, 2008), and insolation was computed 
in the ArcGIS solar radiation module as the average of insolation for each half hour during each $14^{\text {th }}$ day in the year (difuse model: standard overcast sky; diffuse proportion: 0.3; transmittivity: 0.5). Finally, the topographic wetness index was calculated in GRASS GIS using the equation:

$$
T W I=I n \frac{\text { contributing catchement }\left[\mathrm{m}^{2}\right]}{\tan \text { slope }\left[^{\circ}\right]}
$$

The entire study area was then divided into $10 \times 10 \mathrm{~m}$ grid cells as basic statistical units for analysis, with assigned average values for dependent and independent variables.

Regression analysis consisted of several procedures. First, we calculated regressions for each environmental driver against each land cover area or change. We then tested the multi-collinearity of the drivers using a correlation matrix. Because the use of correlated predictor variables violates the assumption of their independence, only one variable from the group of highly correlated variables was used in the multivariate model (Millington et al., 2007). The correlation limit $R>|0.8|$ was used for this purpose (see Tab. 3), as seen in similar works by Gellrich et al. (2007), Martínez (2011) and Rutherford (2008), and referenced to Menard's (2002) recommendation.

We used generalized linear models (GLMs) for analysing the synergic influence of chosen environmental drivers on land cover classes in different years, and for their changes, as recommended by Millington et al. (2007). An individual regression model was calibrated for each response variable using the same set of predictor variables. Linear combinations were used as predictors to incorporate the synergic effects of drivers, and polynomial terms up to the $4^{\text {th }}$ degree (Rutherford, 2007) determined possible non-linear relationships. Exceptions here were combinations with geological variables, which deform the regression design, due to the nominal character of the variables. Because the incorporation of some variables and their derivations not only increase, but can also decrease the model's predictive power, we used automated stepwise backward regression to omit these types of variables.

\section{Results}

\subsection{Land cover change}

The land cover of the study area was identified in five temporal horizons. The development of land cover class areas and land cover spatial distributions in two characteristic years is presented in Figure 2.

The cadastral maps of 1860/68 depict a land cover with distinct boundaries between zones of different intensity of use. Villages with built-up areas and gardens were surrounded by a landscape matrix of arable land, while pastures and meadows occupied less suitable areas. The more distant areas were dominated by meadows, which prevailed over pastures, while forests covered the most unsuitable areas.

Before 1949, there was a significant decrease in arable land, mainly in the steeper and most distant areas, with grassland areas also diminished in favour of forests and shrubs. Cooperative farms were then established between 1961 and 1968, and subsequent collectivization led to a remarkable loss of arable land. In addition, the construction of farm facility buildings reinforced the general increase in artificial surfaces, which was hastened by the spread of family houses. Permanent crop areas increased, especially through orchard establishment in Malachov (Fig. 3 - see cover p. 2). Meanwhile, forests expanded significantly, and grassland and shrub areas grew closer to the settlements. The most significant overall changes were noted in decreased arable land and forest expansion, and these changes continued until 1986.

The land cover in 2011 depicted the changed socio-economic conditions following the transition to a market economy. The most important change was in grassland overgrowth (Fig. 4 - cover p. 2). Here the decrease in bare grassland without scattered trees and shrubs was particularly rapid, almost equalling the rate of decrease in arable land following collectivization, making cultivated meadows a threatened land cover class. Areas affected by forest cutting spread quickly and, combined with the overgrown meadows (Fig. 5 see cover p. 4), they caused an expansion of shrubs.

\subsection{Influence of environmental drivers}

The spatial distribution of the drivers is depicted in Figure 6. The multi-collinearity test in Table 3 defines notable correlations between some factors, thus influencing the interpretation of results. The correlation $r>|0.8|$, which is critical for omitting one of the variables from the multiple regression model, was attained only by radiation and the sine of aspect. When higher interpretation values for radiation were considered, aspect was omitted from the models.

The relationships between land cover and drivers in the chosen years 1949 and 2011 are compared by box-whisker plots in Figure 7, and quantified by simple regression analysis in Figure 8. The most notable relation is the preference for more intensive landuse to concentrate in less steep terrains, thus confirming our hypothesis. This applies in both these years, with the only remarkable change being the arable land shift to the flattest areas in 2011. Regression analysis shows that slope exerted a particularly strong influence on forest areas, with the maximum observed in 1986 . There was also an important influence on the distribution of arable land, especially in the pre-collectivization period, together with an increasing effect on grassland.

The boxplot of the land cover relationship to TWI depicts a similar linear trend to slope (Fig. 7).This is partly

\begin{tabular}{|l|c|c|c|c|c|c|}
\hline & Elevation & Slope & Sin aspect & Radiation & TWI & Distance \\
\hline Elevation & - & 0,3557 & 0,1100 & 0,0405 & $-0,2786$ & 0,6850 \\
\hline Slope & 0,3557 & - & 0,2423 & $-0,2940$ & $-0,4933$ & 0,3602 \\
\hline Sin aspect & 0,1100 & 0,2423 & - & $-0,8598$ & $-0,2200$ & 0,4033 \\
\hline Radiation & 0,0405 & $-0,2940$ & $-0,8598$ & - & 0,0909 & $-0,3219$ \\
\hline TWI & $-0,2786$ & $-0,4933$ & $-0,2200$ & 0,0909 & - & $-0,1764$ \\
\hline Distance & 0,6850 & 0,3602 & 0,4033 & $-0,3219$ & $-0,1764$ & - \\
\hline
\end{tabular}

Tab. 3: Spatial correlation of selected environmental drivers [r] with highlighted correlation $(r>|0.8|)$ 


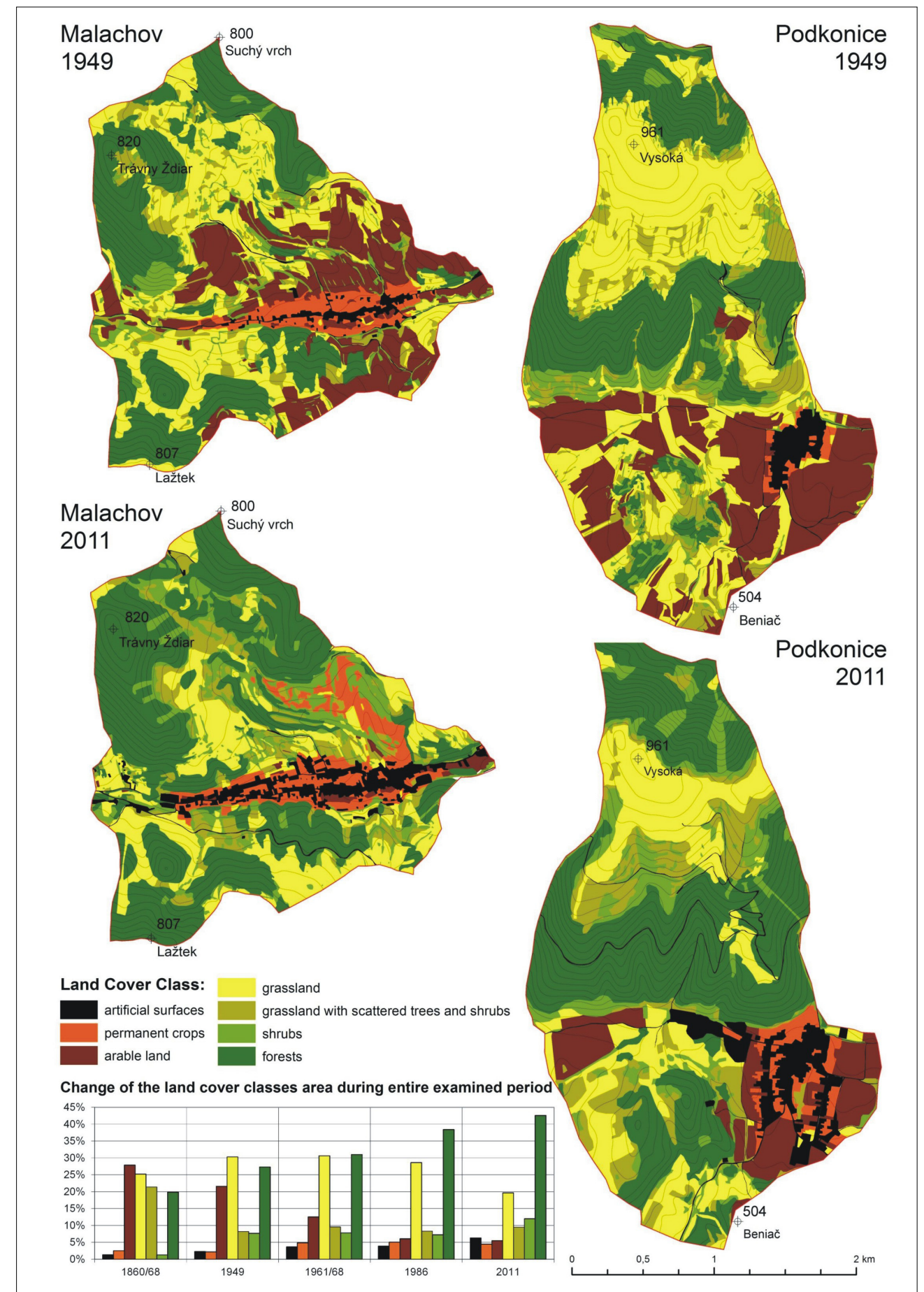

Fig. 2: Land cover of the study areas in the (model) years 1949 and 2011, and the development of area share of land cover classes in all historical horizons

explained by the correlation of both drivers $(\mathrm{r}=-0.49$, Tab. 3), as only weak $\mathrm{R}^{2}$ values were obtained for TWI infuence models (Fig. 8). In relationships to elevation and radiation, the expected difference between the intensively and extensively used areas is notable, as those intensively used areas mostly have values over $850 \mathrm{~kJ} . \mathrm{m}^{-2}$ per day and are situated in areas under $550 \mathrm{~m}$ a.s.l. The influence of distance clearly separates the arable land from the more extensive land use classes, which occupied the more distant areas in both 1949 and 2011 (Fig. 7). According to the simple regression analysis (Fig. 8), geology was established as an important driver for each land cover class. Also, elevation and distance had significant influences on arable land and grassland in the pre-collectivization era.

\subsection{Explaining land cover classes and land cover changes}

The synergic effects of the drivers on land cover were evaluated by GLMs (Fig. 9). Most models had a coefficient of determination between $20 \%$ and $40 \%$. Higher values were achieved for forests, with over $53 \%$ of the variance explained at the last three time points, and for arable land with $42 \%$ to $48 \%$ levels of explanation in the pre-collectivization period. On the other hand, the models for shrubs explain only a negligible part of the spatial variability. These results were reflected also in the simple regression assessment of individual drivers in Figure 8. Only forests and arable land achieved notably strong relationships with some of the drivers, while the remaining classes exhibited average or weak relationships, especially in the case of shrubs. 


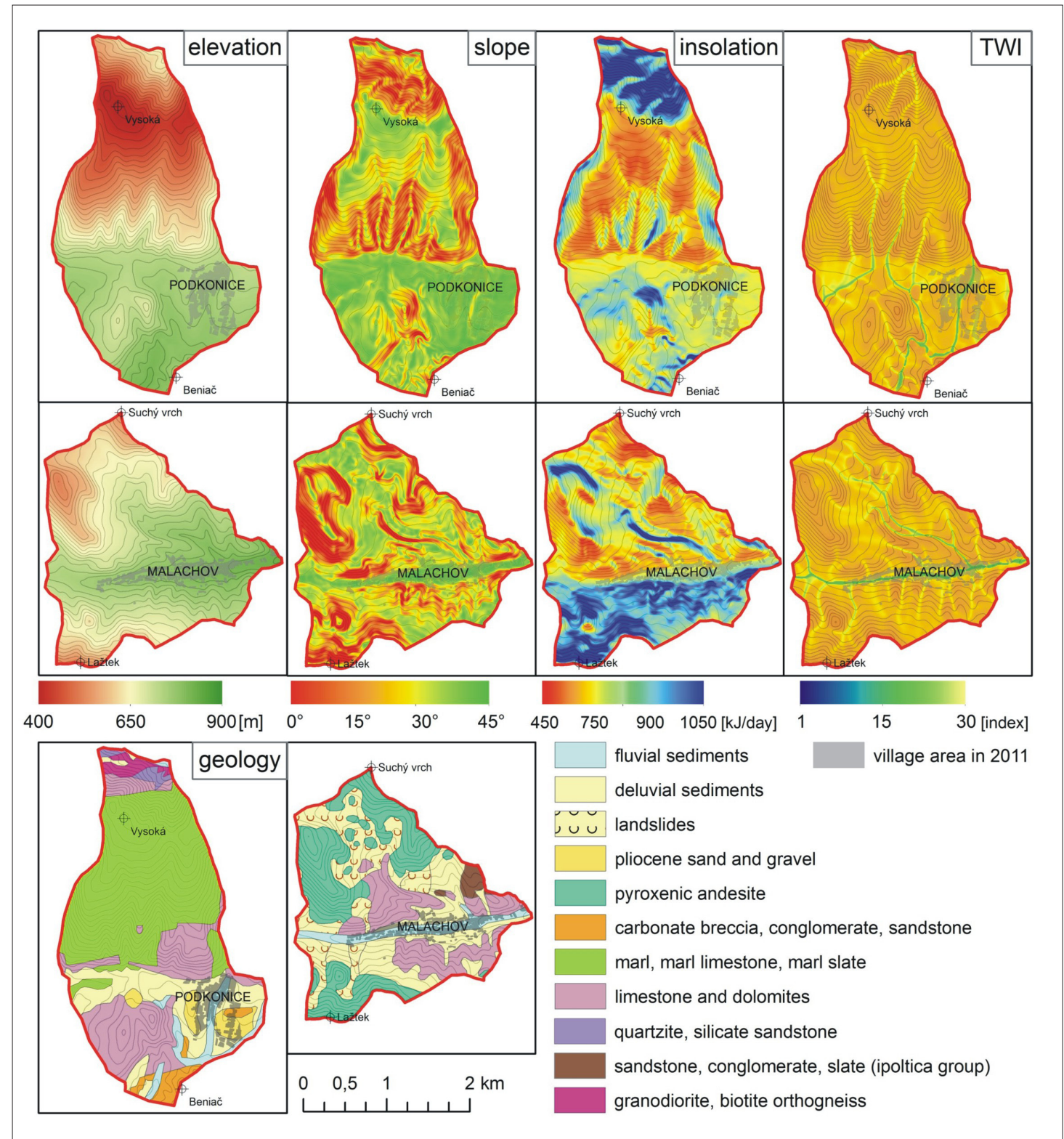

Fig. 6: Spatial distribution of selected environmental drivers in Podkonice and Malachov surroundings

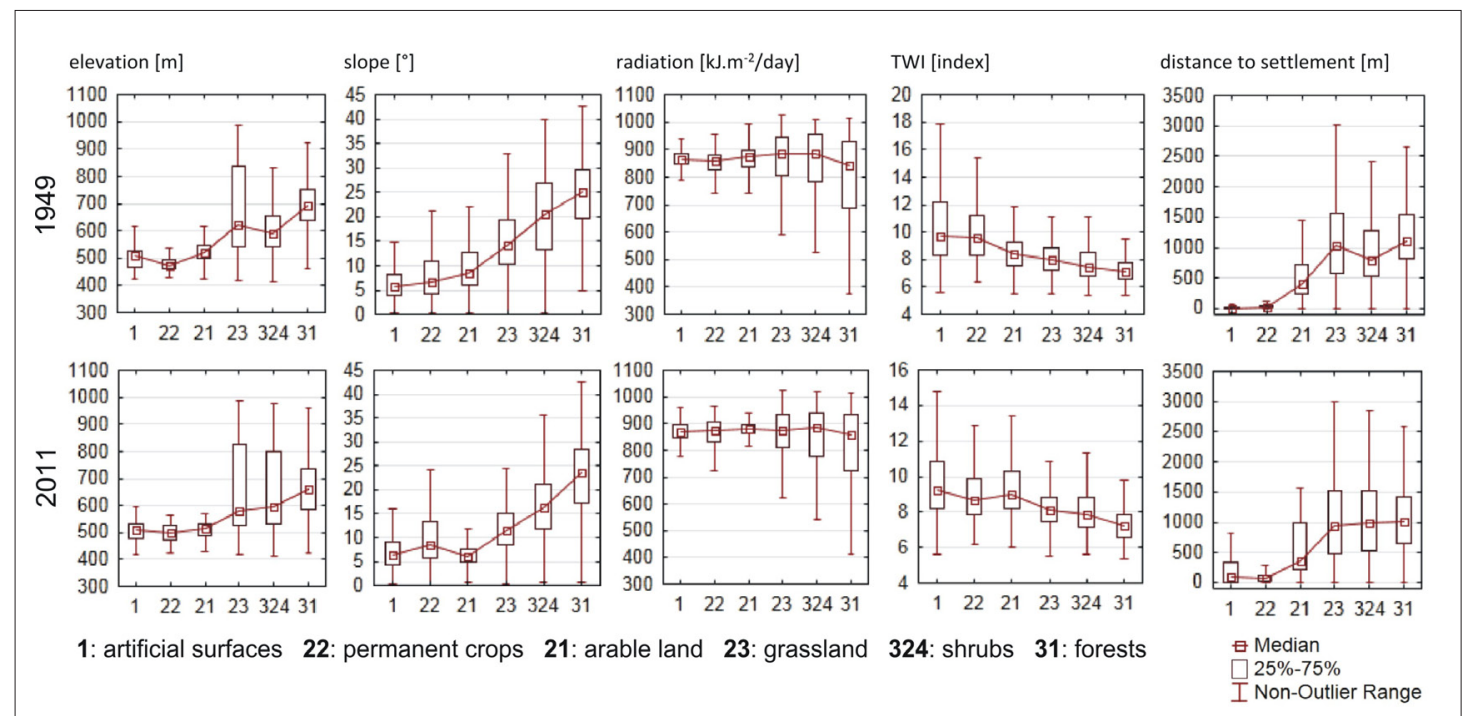

Fig. 7: Distributions of land cover classes on the scale of different predictor variables in the years 1949 and 2011. Note: The land cover classes are sorted according to the intensity of anthropogenic transformation of the natural state (most to least) 
Land cover change processes were also assessed by GLMs in subsequent years, as well as for the period 1949- 2011 (Fig. 10). The models generally achieved lower $\mathrm{R}^{2}$ values for changed areas than for the land cover class areas themselves. Relatively higher values were established for total change in the period 1949-2011 than for the shorter periods between subsequent horizons. Agricultural extensification had the highest level of explained variation, followed by urbanization, while agricultural intensification was explained the least.

\section{Discussion}

\subsection{Land cover change}

The land cover changes discussed here conform to those in other studies in Slovakia (Kopecká, 2006; Cebecauerová, Cebecauer, 2008; Kanianska et al., 2014), where two changes in agricultural organization are noted: (1) the transformation to cooperative farming, with subsequent land collectivization in socialist period; and (2) the reintroduction of the market economy in the 1990s.

The pre-collectivization loss of arable land and the increase in forests are remarkable. This extensification was most likely caused by the combined effects of technological change, emigration and the decreased importance of farming as a livelihood (compare Bičík et al., 2001; Kandrík and Oláh, 2010). Land use extensification is documented in both areas early on, in the period when intensification took place in lower and more favourable areas (Havlíček, Chrudina, 2013). These changes concur with the results of Kanianska, who described arable land expansion in the lowland areas of Slovakia, a slight increase in the submountainous villages, but with decreases in the mountainous settlement areas (Kanianska et al., 2014). This extensification underlines the repressing effect of environmental drivers in mountain villages, but also the effect of proximity to the town of Banská Bystrica, as an industrialized centre offering employment.

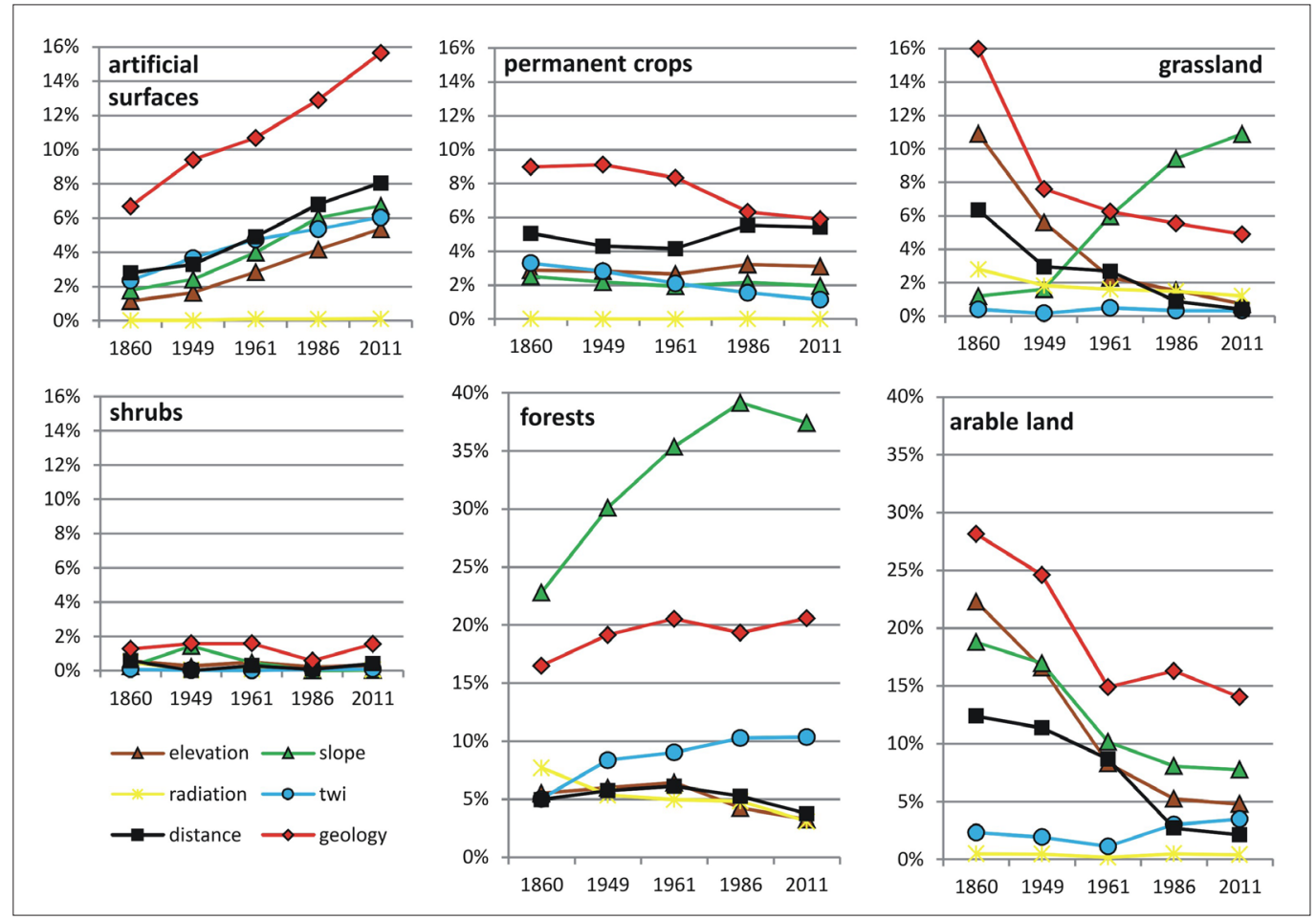

Fig. 8: Influence of partial predictors on the spatial distribution of land cover classes. Simple linear regression was used to calculate $r^{2}$

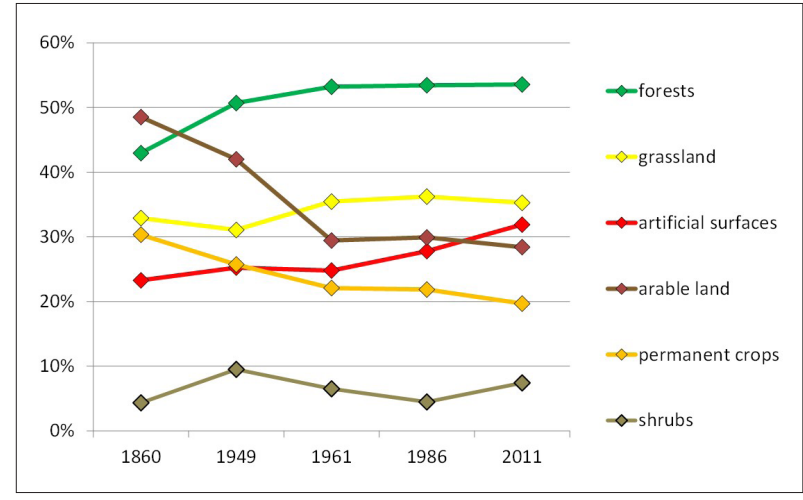

Fig. 9: Coefficients of determination $\left(R^{2}\right)$ of $G L M s$ calibrated for different land cover classes in different years. $R^{2}$ shows the dependence of land cover spatial distribution on the synergic effect of the drivers

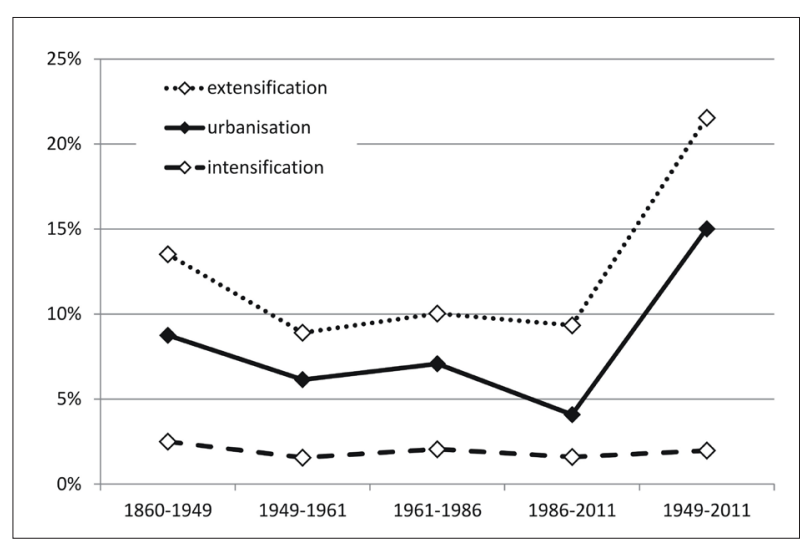

Fig. 10: The influence of the predictors (represented by $R^{2}$ of GLMs) on the spatial distribution of areas of land cover changes in different year intervals 
In the socialist period, there was a rapid decrease in arable land in favour of grassland, despite the overall trend of a spread of arable land as documented in the period 1970-1990 in Slovakia (Feranec et al., 2007). This concurs with the processes of agricultural extensification in mountainous areas, documented in Slovakia (Oláh, 2003; Kandrík, Oláh, 2010), but also in Western Europe (MacDonald et al., 2000; Strijker, 2005). The general trends to urbanization and industrialization also affected our study areas, but no extensive wood harvesting occured during this era. This is contrasted with the remarkable loss of forest areas at the national level (Feranec, Otahel, 2008) and with the high dynamics of forest cover in the Carpathian ecoregion (Griffiths et al., 2013; Main-Knorn et al., 2009), and underlines the fact that forest cover changes are highly dependent on forest management cycles.

The most important land cover process in Slovakia following 1989 was an increase in the shrub-transitional woodland class, which was reinforced by both wood harvesting and the overgrowth of grassland (Feranec, Otahel, 2008). This concurs with the results in Malachov and Podkonice, where the percentage of shrubs (between 7 and 8\% after 1949) increased to $12 \%$ in 2011 . While the forest area also continued to increase, reflecting the national increase, the most notable change involved the retreat of grassland without scattered trees and shrubs, which decreased from $29 \%$ to $20 \%$, greatly affecting the actual landscape appearance.

Besides specific developments in some periods, the few enduring trends throughout this study period are:

1. an increase in forest and artificial surfaces;

2. a very large decrease in arable land; and

3. a shift in classes closer to settlements.

Similar results are described for the moutainous areas by Kanianska et al. (2014) in the village of Liptovská Teplička, by Kandrík and Oláh (2010) in the Lower Spiš region, by Bičík et al. (2001) in the Czech Republic, and in greater detail by Demek et al. (2012) in eastern Moravia. It is possible to consider the areas of Malachov and Podkonice (Fig. 11 - see cover p. 4) as representative of this kind of village territory, since the land cover change processes mostly concur with developments in other mountainous village areas in Slovakia and the Czech Republic.

\subsection{The influence of environmental drivers}

The first hypothesis about the effect of elevation, slope and distance on land cover has been mostly confirmed, as shown by the box-whisker plots (Fig. 7). This influence, though well analyzed in other countries, has been only roughly described in Slovakia by Š́ri (2003) and Kandrík, Oláh (2010), and it has not been assessed by advanced statistical methods at a detailed scale. The influence is particularly obvious in the slope plot, where land cover classes with higher anthropogenic modification preferred less steep terrain in both depicted years. Also elevation and distance diversified the spatial distribution of land cover classes significantly. The absolute maximum distance of fields from a settlement was $1.5 \mathrm{~km}$ in 1949 (Fig. 7), slightly exceeding the maximal diameter of $1.2 \mathrm{~km}$, stated by Löw and Míchal (2003).

Individual regression analyses specified the influence of the drivers (Fig. 8). The influence is not so dominant for all land cover classes, and it also changes over time (compare Aspinall, 2004). Models relating slope and forests had the highest coefficients of determination, and this confirms the strong relative predisposition of steep areas for forestry. This influence has increased in recent years, most likely because steep areas were often previously used as pastures in the zone of intensive agriculture and as forests in the extensive zone, while they are all usually reforested now. The relatively strong influence of slope was detected by the models for arable land before collectivization, and for grassland after it. Since transition of many fields into meadows followed the introduction of collectivization, these models most likely partly depict relationships occurring in the same area. This underlines the shift in agricultural demands on the environment, where fields held by private farmers in the past are now suited only to tractor mowing.

According to many studies, elevation and distance are typically strong factors (e.g., Martínez, 2011; Hietel et al., 2004). In this study, these factors are particularly important for the localization of grassland and arable land, especially in the pre-collectivization period. This confirms the previous statement that the zones of intensive and extensive agriculture had distinct boundaries. The influence of elevation and distance is relatively similar for all land cover classes, mainly because of their corresponding high spatial correlation. We assume that this correlation is high for most villages in mountainous regions, as they are situated on the valley floor. Such high correlations are a reason for omitting elevation from the models in some studies (Gellrich et al., 2007; Millington et al., 2007). Therefore it is reasonable to aggregate these variables in one variable which defines area accessibility, although this would ignore the climatological aspects of elevation.

Verification of the second hypothesis about the insolation effect on land cover is disputable. According to the box-plots, there is a weak trend distinguishable, where grassland, shrubs and forests occupy areas with higher amplitude and decreasing insolation (Fig. 7). This relationship is not very strong because the effect of insolation is practically insignificant for each land cover type, according to the simple regressions. On the other hand, insolation is valuable in the multiple regression models because it is seldom correlated with other variables and has an important discrete interpretation.

Geology was used as a proxy for the physical and chemical attributes of the soil substrate in the regression models, since available soil maps were not sufficient at this scale. In other studies (Hietel et al., 2004; Martínez, 2011) soil attributes have mostly minor or average influence, although Baumann (2011) found an important influence of cambisols. Geology appears to be one of the most important drivers according to the models (Fig. 8) in this study, however. This may be validly interpreted by considering the fact that geological data were used at the nominal scale, with 11 classes defined as individual binominal (or dummy) variables, and with many of them occurring only in limited areas. Another possible interpretation is that the spatial distribution of individual geological substrate classes carries aggregated information on more landscape attributes. For example, the villages are preferably established on the valley floor. This area has a better correlation with the extent of fluvial sediments, than with low slopes or high TWI. Interpretations based solely on geological substrate type could therefore be misleading. This finding could be an argument for using predictor variables with aggregated information in simple regressions, because these could explain land cover spatial variability more precisely than individual landscape parameters. In multiple regression, however, these variables should be replaced by variables defining landscape properties more specifically to avoid the problems of multicollinearity. 
TWI was used to express water availability and soil wetness (Martínez, 2011; Rutherford, Bebi, 2008), but its interpretation appeared to be problematic in this study. Since TWI is derived from the catchment area and the slope, most of its $R^{2}$ can be explained by its correlation with slope, rather than as a unique influence. Therefore an alternative index, not derived from slope, may provide better assessment of the actual wetness influence. Another solution is the use of (1) GLMs calibrated with the complex of environmental drivers, and (2) hierarchical partitioning, which would be able to estimate the individual contribution of TWI to the total variance explained by a model (Millington et al., 2007).

\subsection{The explanation of land cover classes and land cover changes}

GLMs were calculated to assess the overall and combined effect of environmental predictors (drivers) on land cover: several significant findings have been revealed.

The most remarkable finding is the decrease in arable land variability explained by the model during collectivization (Fig. 9). This means that the extent of arable land became less determined by the influence of environmental drivers. The decrease may be interpreted as the effect of agricultural re-organization under cooperative farming, where environmental conditions were not reflected to the same extent as in earlier private farming. The $R^{2}$ increase in grassland is associated with this arable land decrease, reflecting the process of direct transition between these two land cover classes as described previously.

The highest $\mathrm{R}^{2}$ values were attained by the models of forest area variability, concurring with the results of the simple regressions. Their slightly increasing trend indicates that the overall increase in forest area was the optimalization of use of areas unsuitable for agriculture. The ability of the models to explain the spatial distribution of artificial surfaces and permanent crops is relatively low, but they still achieved notable values between $20 \%$ and $30 \%$. The artificial surfaces $R^{2}$ tended to increase with overall area increase. The permanent crops $R^{2}$ decrease can be interpreted by the establishment of orchards in Malachov in the area where fields previously existed and which have different environmental conditions from areas of gardens. The spatial distribution of shrubs is almost completely unrelated to the selected predictor variables, as they exist in a variety of areas, ranging from glades to field boundaries. Dividing them into separate categories, however, would increase their explanation by the models, and this is also our suggestion for other land cover change driver studies that apply the CORINE Land Cover methodology.

Many land cover change studies focus solely on the areas of change (e.g., Martínez, 2011; Millington et al., 2007; Schneider, Pontius, 2001; Tasser et al., 2007). In this study the land cover changes were noticeably explained more poorly by the models, compared to the land cover classes in separate years. Therefore we suggest that focusing on the areas of the land cover class real extent in different years, in addition to the area of change, could help to better understand the spatial driver effects.

Our land cover change models explained agricultural extensification processes better than both agricultural intensification and urbanization, similar to the results of the Rutherford and Bebi (2008) study. Also the processes in the longer period between 1949 and 2011 were evidently better explained. This indicates that total areas of change over this long period were more homogenous than the areas with partial change in subsequent years. In turn, this suggests that extensification and urbanization process drivers act over longer periods, with possible inner fluctuations.

\section{Conclusions}

This detailed analysis has confirmed that land cover development in these two study areas mostly reflected similar developments to those described in Slovakia more generally. The most important processes were the rapid reduction of arable land, the spread of forests and increases in artificial surfaces, as well as an excessive spread of shrubs and reduction of grassland in the most recently observed period. The minor differences highlighted in this discussion delineate the variability of land cover processes recorded in different areas and at different scales. This finding underlines the need for detailed land cover classifications in other studies at a local level.

The hypothesis, that higher slope, elevation and distance to settlement were related to the classes with lower intensity of use, was mostly confirmed. Generally, slope exhibited notable influences in each model, while elevation and distance from settlement were significant in individual cases. Geology was also important for each land cover class distribution, which was probably caused by the fact that this variable was defined at a nominal scale with 11 geological substrate classes.

The synergic influence of drivers on land cover and its changes was assessed by generalized linear models (GLMs). Forests were the most explicable land cover class $\left(R^{2}\right.$ values ranging from $43 \%$ to $53 \%$ ), while arable land during precollectivization and grassland in post-collectivization were also considerably related to the drivers. On the other hand, shrubs were almost completely unrelated to these investigated drivers. The extent of areas of land cover change were not so well explained by the GLMs, although relatively better results were achieved with the analysis of change over a longer time period (up to $22 \%$ ), and also for the extensification changes ( $\mathrm{R}^{2}$ from $9 \%$ to $14 \%$ ).

The statistical tools used in this study were adequate for depicting and quantifying the relationships between land cover and environmental conditions. Interpretation requires a logical approach, however, as results can reflect not only actual influences but also other effects, including the multicollinearity of the drivers and differences due to the mixed use of nominal and interval scaled data.

Land cover change is influenced by a much greater number of spatial drivers than those assessed by our models, including the area's biophysical conditions, structural properties and socio-economic background. Land cover change itself, moreover, remains dependent on landowners who decide on the usage or abandonment of a particular area (Gellrich et al., 2007; Van Doorn, Bakker, 2007). In conclusion, the most valuable variables which could increase the explanatory power of statistical models should reflect real land use decision-making processes.

\section{Acknowledgements}

We would like to thank two anonymous reviewers for their valuable comments and constructive criticism. This study was supported by the Slovak Research and Development Agency under contract No. APVV-0625-11, by the Scientific Grant Agency of the Ministry of Education of the Slovak Republic and Slovak Academy of Science (projects No. 1/0208/12 and No. 1/1155/12), and by the Comenius University Grant No. UK/100/2013. 


\section{References:}

ASPINALL, R. (2004): Modelling land use change with generalized linear models - a multi-model analysis of change between 1860 and 2000 in Gallatin Valley, Montana. Journal of environmental management, Vol. 72, No. 1-2, p. 91-103.

BAUMANN, M., KUEMMERLE, T., ELBAKIDZE, M., OZDOGAN, M., RADELOFF, V. C., KEULER, N. S., PRISHCHEPOV, A. V., KRUHLOV, I., HOSTERT, P. (2011): Patterns and drivers of post-socialist farmland abandonment in Western Ukraine. Land Use Policy, Vol. 28, No. 3, p. 552-562.

BIČÍK, I., JELEČEK, L., ŠTĚPÁNEK, V. (2001): Land-use changes and their social driving forces in Czechia in the $19^{\text {th }}$ and $20^{\text {th }}$ centuries. Land Use Policy, Vol. 18, No. 1, p. 65-73.

BOLTIŽIAR, M., BRU゚NA, V., KŘOVÁKOVÁ, K. (2008): Potential of antique maps and aerial photographs for landscape changes assessment - an example of High Tatras. Ekológia, Vol. 27, No. 1, p. 65-81.

BÜRGI, M., HERSPERGER, A. M., SCHNEEBERGER, N. (2004): Driving forces of landscape change - current and new directions. Landscape Ecology, Vol. 19, No. 8, p. 857-868.

CALVO-IGLESIAS, M. S., FRA-PALEO, U., DIAZ-VARELA, R. A. (2009): Changes in farming system and population as drivers of land cover and landscape dynamics: The case of enclosed and semi-open field systems in Northern Galicia (Spain). Landscape and Urban Planning, Vol. 90, No. 3-4, p. 168-177.

CEBECAUEROVÁ, M., CEBECAUER, T. (2008): Spatiotemporal trends of landscape developenment in southwest part of Slovakia. Ekológia, Vol. 2, No. 27, p. 212-228.

DEMEK, J., MACKOVČIN, P., SLAVÍK, P. (2012): Spatial and temporal trends in land-use changes of Central European landscapes in the last 170 years: a case study from the south-eastern part of the Czech Republic. Moravian Geographical Reports, Vol. 20, No. 3, p. 2-22.

DOMON, G., BOUCHARD, A. (2007): The landscape history of Godmanchester (Quebec, Canada): two centuries of shifting relationships between anthropic and biophysical factors. Landscape Ecology, Vol. 22, No. 8, p. 1201-1214.

FALŤAN, V., BÁNOVSKÝ, M., BLAŽEK, M. (2011): Evaluation of land cover changes after extraordinary windstorm by using the land cover metrics: a case study on the High Tatras foothill. Geografie, Vol. 2, No. 116, p. $156-171$.

FALŤAN, V., PAZÚROVÁ, Z. (2010): Hodnotenie poškodenia vegetácie veternou kalamitou na rôznych typoch geotopov v okolí Danielovho domu (Vysoké Tatry). Geografický časopis, Vol. 1, No. 62, p. 75-88.

FERANEC, J., HAZEU, G., CHRISTENSEN, S., JAFFRAIN, G. (2007): Corine land cover change detection in Europe (case studies of the Netherlands and Slovakia). Land Use Policy, Vol. 24, No. 1, p. 234-247.

FERANEC, J., JAFFRAIN, G., SOUKUP, T., HAZEU, G. (2010): Determining changes and flows in European landscapes 1990-2000 using CORINE land cover data. Applied Geography. Vol. 30, No. 1, p. 19-35.

FERANEC, J., NOVÁČEK, J. (2009): The CORINE land cover database of Slovakia and its changes in the period 2000-2006. Moravian Geographical Reports. Vol. 17, No. 3, p. 2-9.

FERANEC, J., OŤAHEL, J. (1999): Mapovanie krajinnej pokrývky metódou Corine v mierke 1:50 000: návrh legendy pre krajiny programu Phare. Geografický časopis, Vol. 51, No. 1, p. 19-35.

FERANEC, J., OŤAHEL, J. (2008): Land cover changes in Slovakia in the period 1970-2000. Geografický časopis, Vol. 60, No. 2, p. 113-128.

FLORINSKY, I. V., KURYAKOVA, G. A. (1996): Influence of topography on some vegetation cover properties. CATENA, Vol. 27, No. 2, p. 123-141.

GELLRICH, M. et al. (2007): Agricultural land abandonment and natural forest re-growth in the Swiss mountains: A spatially explicit economic analysis. Agriculture, Ecosystems \& Environment, Vol. 118, No. 1-4, p. 93-108.

GRIFFITHS, P., KUEMMERLE, T., BAUMANN, M., RADELOFF, V. C., ABRUDAN, I. V., LIESKOVSKY, J., MUNTEANU, C., OSTAPOWICZ, K., HOSTERT, P. (2014): Forest disturbances, forest recovery, and changes in forest types across the Carpathian ecoregion from 1985 to 2010 based on Landsat image composites. Remote Sensing of Environment, Vol. 151, p. 72-88.

HARRISON, S., MASSEY, D., RICHARDS, K., MULDAVIN, J., WALSH, S. J., MCGINNIS, D., EVANS, T. P., KELLEY, H. (2008): Assessing the transition from deforestation to forest regrowth with an agent-based model of land cover change for south-central Indiana (USA). Geoforum, Vol. 39, No. 2, p. 819-832.

HAVLÍČEK, M., CHRUDINA, Z. (2013): Long-term land use changes in relation to selected relief characteristics in western carpathians and western pannonian basin case study from Hodonín District (Czech Republic). Carpathian Journal of Earth and Environmental Sciences, Vol. 8, No. 3, p. 231-244.

HIETEL, E., WALDHARDT, R., OTTE, A. (2004): Analysing land-cover changes in relation to environmental variables in Hesse, Germany. Landscape Ecology. Vol. 19, No. 5, p. 473-489.

HIETEL, E., WALDHARDT, R., OTTE, A. (2005): Linking socio-economic factors, environment and land cover in the German Highlands, 1945-1999. Journal of Environmental Management, Vol. 75, No. 2, p. 133-143.

IVANOVÁ, M., MICHAELI, E., BOLTIŽIAR, M., JUHAŠČÍKOVÁ, J. (2012): Analysis of landscape heterogeneity changes on the example of Hlinné, Vyšný Žipov, and Zlatník village (Eastern Slovakia) in the period of 1826-2006. Ekológia, Vol. 30, No. 2, p. 269-280.

KANDRÍK, R., OLÁH, B. (2010): Land use development in the central part of the spiš region (Slovakia) since the $18^{\text {th }}$ century. Moravian Geographical Reports, Vol. 18, No. 4, p. 10-20.

KANIANSKA, R., KIZEKOVÁ, M., NOVÁČEK, J., ZEMAN, M. (2014): Land-use and land-cover changes in rural 
areas during different political systems: A case study of Slovakia from 1782 to 2006. Land Use Policy, Vol. 36, p. 554-566.

KOPECKÁ, M. (2006): Identifikcia a hodnotenie zmien krajiny vo vel'kej mierke (na príklade okolia Trnavy). Geografický časopis, Vol. 58, No. 2, p. 125-148.

LIESKOVSKÝ, J., KANKA, R., BEZÁK, P., ŠTEFUNKOVÁ, D., PETROVIČ, F., DOBROVODSKÁ, M. (2013): Driving forces behind vineyard abandonment in Slovakia following the move to a market-oriented economy. Land Use Policy, Vol. 32, p. 356-365.

LIPSKÝ, Z. (2001): Monitoring changes in the cultural landscape. Praha: ČZU Praha. 71 pp.

LÖFVENHAFT, K., RUNBORG, S., SJÖGREN-GULVE, P. (2004): Biotope patterns and amphibian distribution as assessment tools in urban landscape planning. Landscape and Urban Planning, Vol. 68, No. 4, p. 403-427.

LÖW, J., MÍCHAL, I. (2003): Krajinný ráz. Kostelec nad Černými lesy: Lesnická práce. 552 pp.

MACDONALD, D., CRABTREE, J., WIESINGER, G. (2000): Agricultural abandonment in mountain areas of Europe: environmental consequences and policy response. Journal of Environmental Management, Vol. 59, No. 1, p. 47-69.

MAIN-KNORN, M., HOSTERT, P., KOZAK, J., KUEMMERLE, T. (2009): How pollution legacies and land use histories shape post-communist forest cover trends in the Western Carpathians. Forest Ecology and Management, Vol. 258, No. 2, p. 60-70.

MARTÍNEZ, J.Á. (2011): Modelling the risk of land cover change from environmental and socio-economic drivers in heterogeneous and changing landscapes: The role of uncertainty. Landscape and Urban Planning, Vol. 101, No. 1, p. 108-119.

MENARD, S. (2002): Applied logistic regression analysis. Thousand Oaks, Sage Publications. 111 pp.

MILLINGTON, J. D. A., PERRY, G. L. W., ROMEROCALCERRADA, R. (2007): Regression Techniques for Examining Land Use/Cover Change: A Case Study of a Mediterranean Landscape. Ecosystems, Vol. 10, No. 4, p. 562-578.

MONTEIRO, A. T., FAVA, F., HILTBRUNNER, E., DELLA MARIANNA, G., BOCCHI, S. (2011): Assessment of land cover changes and spatial drivers behind loss of permanent meadows in the lowlands of Italian Alps. Landscape and Urban Planning, Vol. 100, No. 3, p. 287-294.

MOTTET, A., LADET, S., COQUÉ, N., GIBON, A. (2006): Agricultural land-use change and its drivers in mountain landscapes: A case study in the Pyrenees. Agriculture, Ecosystems \& Environment, Vol. 114, No. 2-4, p. 296-310.

MÜLLER, D., KUEMMERLE, T., RUSU, M., GRIFFITHS, P. (2009): Lost in transition: determinants of post-socialist cropland abandonment in Romania. Journal of Land Use Science, Vol. 4, No. 1-2, p. 109-129.

MÜLLER, D., MUNROE, D. K. (2008): Changing Rural Landscapes in Albania: Cropland Abandonment and Forest Clearing in the Postsocialist Transition. Annals of the Association of American Geographers, Vol. 98, No. 4, p. 855-876.
NASSAUER, J. (1995): Culture and changing landscape structure. Landscape Ecology, Vol. 10, No. 4, p. 229-237.

OLÁH, B. (2003): Vývoj využitia krajiny Podpolania: Starostlivost' o kultúrnu krajinu prechodnej zóny Biosférickej rezervácie Pol'ana. Zvolen, Vydavatel'stvo Technickej univerzity vo Zvolene, $110 \mathrm{pp}$.

OLÁH, B., BOLTIŽIAR, M., PETROVIČ, F. (2006): Land use changes relation to georelief and distance in the East Carpathians Biosphere Reserve. Ekológia (Bratislava), Vol. 25, No. 1, p. 68-81.

PRISHCHEPOV, A. V., MÜLLER, D., DUBININ, M., BAUMANN, M., RADELOFF, V. C. (2013): Determinants of agricultural land abandonment in post-Soviet European Russia. Land Use Policy, Vol. 30, No. 1, p. 873-884.

RUTHERFORD, G. (2007): Evaluating sampling strategies and logistic regression methods for modelling complex land cover changes. Journal of Applied Ecology, Vol. 44, No. 2, p. 414-424.

RUTHERFORD, G., BEBI, P. (2008): Assessing land-use statistics to model land cover change in a mountainous landscape in the European Alps. Ecological Modelling, Vol. 212, No. 3-4, p. 460-471.

SENKO, D., MIŠKOVIC, J., GALLAY, M., SENKOVÁBALDAUFOVÁ, K. (2008): Dynamika zmien vegetácie na Devínskej kobyle a jej predikcia. Geografický časopis, Vol. 60, No. 4, p. 319-338.

SERRA, P., PONS, X., SAURÍ, D. (2008): Land-cover and land-use change in a Mediterranean landscape: A spatial analysis of driving forces integrating biophysical and human factors. Applied Geography, Vol. 28, No. 3, p. 189-209.

SCHNEEBERGER, N., BÜRGI, M., HERSPERGER, A. M., EWALD, K. C. (2007): Driving forces and rates of landscape change as a promising combination for landscape change research - An application on the northern fringe of the Swiss Alps. Land Use Policy, Vol. 24, No. 2, p. 349-361.

SCHNEIDER, L., PONTIUS, R. G. (2001): Modeling landuse change in the Ipswich watershed, Massachusetts, USA. Agriculture, Ecosystems \& Environment, Vol. 85, No. 1-3, p. 83-94.

STRIJKER, D. (2005): Marginal lands in Europe - causes of decline. Basic and Applied Ecology, Vol. 6, No. 2, p. 99-106.

ŠÚRI, M. (2003): Vplyv reliéfu na diferenciáciu krajinnej pokrývky Slovenska. Geografický časopis, Vol. 55, No. 1, p. 41-58.

ŠTÁTNY GEOLOGICKÝ ÚSTAV DIONÝZA ŠTÚRA (2011): Geologická mapa Slovenska M 1:50 000. [online]. Bratislava [cit. 27.3.2012]. Available at: http://mapserver. geology.sk/gm50js/

TASSER, E., WALDE, J., TAPPEINER, U., TEUTSCH, W. (2007): Land-use changes and natural reforestation in the Eastern Central Alps. Agriculture, Ecosystems \& Environment, Vol. 118, No. 1-4, p. 115-129.

VAN DOORN, A. M., BAKKER, M. M. (2007): The destination of arable land in a marginal agricultural landscape in South Portugal: an exploration of land use change determinants. Landscape Ecology, Vol. 22, No. 7, p. 1073-1087. 
VON THUNEN, J. H. (1826): Der isolierte Staat in Beziehung auf Land- wirtschaft und Nationalökonomie. Hamburg.

WEAR, D., BOLSTAD, P. (1998): Land-use changes in southern Appalachian landscapes: spatial analysis and forecast evaluation. Ecosystems, Vol. 1, No. 6, p. 575-594.
WU, K., ZHANG, H. (2012): Land use dynamics, built-up land expansion patterns, and driving forces analysis of the fast-growing Hangzhou metropolitan area, eastern China (1978-2008). Applied Geography, Vol. 34, p. 137-145.

\section{Authors' addresses:}

Mgr. Michal DRUGA, e-mail: michal.druga@uniba.sk Assoc. Prof. RNDr. Vladimír FALŤAN, Ph.D., e-mail: vladimir.faltan@uniba.sk

Department of Physical Geography and Geoecology

Faculty of Natural Sciences of Comenius University in Bratislava

Mlynská dolina, 84215 Bratislava 4, Slovakia

Initial submission 19 July 2013, final acceptance 25 February 2014

Please cite this article as:

DRUGA, M., FALŤAN, V. (2014): Influences of environmental drivers on land cover structure and its long-term changes: A case study of the villages of Malachov and Podkonice in Slovakia. Moravian Geographical Reports, Vol. 22, No. 3, p. 29-41. DOI: 10.2478/mgr-2014-0016 